\title{
OS ÁRBITROS DE FUTEBOL E A MÍDIA ESPORTIVA: A INTERPRETAÇÃO DE ÁRBITROS PAULISTAS SOBRE OS COMENTÁRIOS DA MÍDIA ACERCA DO TRABALHO DA EQUIPE DE ARBITRAGEM
}

\author{
FOOTBALL REFEREES AND SPORTS MEDIA: SÃO PAULO FOOTBALL \\ REFEREES' VIEWS OVER MEDIA COMMENTS ABOUT THE WORK OF \\ REFEREE TEAMS
}

ÁRBITROS DE FÚTBOL Y LOS MEDIOS DE COMUNICACIÓN DEPORTIVA: COMENTARIOS DE LOS ARBITORS PAULISTAS A CERCA DEL TRABAJO DE LA EQUIPO DE ARBITRAJE

\section{Carla Righeto*, Heloisa Helena Baldy dos Reis ${ }^{\star \star}$}

Palavras chave:

Futebol.

Meios de

comunicação de

massa.

Violência.
Keywords:

Football.

Mass media

Violence.
Resumo: Este artigo é resultado de uma pesquisa com os árbitros da Federação Paulista de Futebol categoria FIFA. Entrevistamos em 2015 os três árbitros pertencentes a esta categoria. As entrevistas foram semiestruturadas e o recorte feito para este artigo teve por objetivo compreender como estes árbitros percebem e interpretam os comentários que a mídia faz do trabalho da equipe de arbitragem. A teoria do processo civilizatório de Norbert Elias e os estudos sobre violência de Elias e Eric Dunning são o nosso referencial teórico. Para os árbitros, os comentários da mídia sobre as suas decisões em lances considerados duvidosos e polêmicos no jogo são desumanos, uma vez que os jornalistas e comentaristas possuem recursos (tecnológicos) de análises não disponíveis aos árbitros.

Abstract: This article is the result of a survey conducted with football referees of the São Paulo Football Federation included in the so-called FIFA category. We interviewed three referees in the second half of 2015. Interviews were semi-structured in order to understand how those referees see and interpret media comments on the work of referee teams. The study's reference was Norbert Elias's theory of civilizing processes and Elias, Dunning about violence. Referees see media comments on their decision about dubious situations as inhumane since journalists and commentators have technology resources that are not available to referees.

Palabras clave:

Fútbol.

Medios de

comunicación de

masas.

Violencia.
Resumen: Este artículo es el resultado de una encuesta sobre la categoría FIFA árbitros de fútbol. Entrevistado en el segunda mitad de 2015, tres árbitros pertenecientes a la junta de arbitraje de la Federación de Fútbol de São Paulo, a través de entrevistas semiestructuradas que tuvo como objetivo comprender cómo estos árbitros sienten e interpretan los comentarios de la prensa acerca de la actuación del árbitro. El marco de la investigación es la teoría de los procesos civilizadores de Norbert Elias y los estudios sobre violencia de Elias y Eric Dunning .Los árbitros consideran cómo inhumano las evaluaciones de los medios de comunicación, ya que los periodistas y comentaristas tienen condiciones de análisis no disponibles a los árbitros, estos interpretan los comentarios como una forma de violencia simbólica.
*Rede Municipal de Ensino de Campinas. Campinas, SP, Brasil. E-mail: carlarigheto@uol.com.br.

**Universidade Estadual de Campinas. Campinas, SP, Brasil. E-mail: heloreis14@gmail.com

Recebido em: 15-01-2016 Aprovado em: 16-10-2016 (c) (1) (8) Licence 


\section{INTRODUÇÃO'}

No séculoXIX a Inglaterra, berço do esporte moderno, viveu uma série de transformações sociais, políticas e econômicas. A Revolução Industrial normatizava o trabalho e projetava o desenvolvimento econômico, o parlamentarismo propunha um jogo político civilizado e as diferentes formas de restrições sociais impostas à população tinham por objetivo melhorar o convívio social nos espaços públicos. A regulamentação de várias modalidades esportivas surge na Inglaterra nessa época, acompanhando este cenário vivido pelo país. Segundo Reis e Escher (2006, p. 20):

$\mathrm{Na}$ fase anterior à esportivização (adoção de regras universais), os jogos eram regulamentados por tradições locais, sendo assim variáveis suas regras de um local a outro. A normatização desses jogos na Inglaterra passou por vários "estágios", até se chegar ao que hoje é denominado de esporte.

Era uma época de padronização, o Estado estabelecia a constituição, leis, decretos e códigos; as instituições informais criavam suas regras, normas e costumes; os esportes se institucionalizavam e iniciava-se o processo de padronização das regras esportivas.

As universidades de Oxford e Cambridge e as instituições de ensino (public schools), que inicialmente eram encarregadas da educação de alunos pobres (séculos XVIII e parte do XIX), sofreram transformações ao final do século XIX, tornando-se internatos pagos para estudantes da classe média alta e classe alta. Essas escolas foram de fundamental importância para o processo de codificação das regras do futebol moderno. Sobretudo porque as práticas de um jogo com bola entre os estudantes faziam parte das rotinas escolares, porém cada escola estabelecia e jogava o futebol com regras e costumes próprios.

O empenho dos alunos e ex-alunos dessas instituições de ensino para que se chegasse à unificação das regras do jogo foi coroado no dia 26 de outubro de 1863 em um pub na cidade de Londres, data de fundação da Football Association (FA), que se tornou a responsável por reger o futebol local. Segundo Coelho (2002, p.137),

Em 1863, alunos e ex-universitários de Cambridge, sob a liderança do jornalista John Cartwright, iniciam uma campanha para a padronização das regras. Depois de muita discussão, finalmente representantes de várias escolas reúnem-se na Freemason's Tavern, em Londres, em 26 de outubro, para criar a The Football Association (FA), que até hoje é a responsável pelo futebol inglês. Na mesma reunião formou-se um comitê incumbido de redigir as novas regras. Em 24 de novembro, uma assembleia aprovou o texto e no dia 8 de dezembro a FA publicou-o na grande imprensa.

A Football Association inspirou o surgimento das outras federações e foi decisiva para o desenvolvimento do futebol. A realização de torneios e as disputas eram facilitadas pelo surgimento dos novos meios de transporte. Profissionais ingleses que iam trabalhar em outros países e nas colônias inglesas ajudavam a divulgar o futebol, pois queriam continuar a prática desse esporte. Jovens que iam estudar na Inglaterra aprendiam a jogar futebol e retornavam aos seus países de origem com o livro de regras e bolas na bagagem. Foi o que aconteceu com Charles Willian Miller, considerado no mito de origem o "pai do futebol no Brasil".

São 152 anos de história de um esporte que nasceu das práticas de jogos populares que foram ressignificados nas escolas públicas inglesas, sendo consagrado ao longo do

1 Pesquisa realizada sob Parecer Comitê de Ética 1.164.183. 
século XX como um fenômeno mundial. A fundação da Football Association, em 1863, e posteriormente, em 1904, a fundação da Fédération Internationale de Football Association (FIFA), promoveram o desenvolvimento e o crescimento do futebol, sua profissionalização e espetacularização. Os jornalistas e a imprensa fizeram parte de todo esse processo de desenvolvimento.

Se nas primeiras regras do jogo não existiam os árbitros, o desenvolvimento e 0 crescimento do futebol fizeram com que as disputas fossem mais acirradas e os árbitros adentrassem o campo em 1891.

O interesse em assistir aos jogos de futebol começou no final do século XIX. Se a profissionalização é considerada um marco para o crescente interesse do futebol, o papel da imprensa na divulgação do futebol e, portanto, sua contribuição para o seu desenvolvimento foi e continua sendo fundamental, desde as primeiras reuniões dos estudantes das escolas públicas inglesas pela unificação das regras. As transmissões das partidas no Brasil pelo rádio na década de 1930 e na televisão, que surge na década de 1950, foram fatores importantes para que o futebol se tornasse um fenômeno de massa.

Hoje as emissoras de TV investem cada vez mais nas transmissões dos jogos, no jornalismo esportivo e nos programas de debate. Utilizando-se de recursos de captação e edição de imagens, do videotape e da paixão do povo brasileiro pelo futebol, especialistas e jornalistas fazem análises técnicas e táticas das equipes, entrevistas com os "atores" do espetáculo e analisam e comentam os supostos erros da equipe de arbitragem. Lances duvidosos e polêmicos de uma partida rendem horas de debate na programação esportiva. Criticar o trabalho da equipe de arbitragem tornou-se uma prática comum no meio jornalístico. Distante da possibilidade de usufruir dos avanços tecnológicos disponibilizados pela mídia está o árbitro de futebol, que necessita tomar decisões rápidas durante a partida de futebol.

O recorte feito da pesquisa ${ }^{2}$ para esse artigo objetiva compreender como os árbitros entrevistados sentem e interpretam os comentários feitos na mídia a respeito da atuação da equipe de arbitragem durante uma partida de futebol.

Entrevistamos os três árbitros FIFA da Federação Paulista de Futebol ${ }^{3}$, ou seja, 100\% dos árbitros classificados na categoria máxima da arbitragem em futebol, dois homens e uma mulher. As entrevistas foram semiestruturadas, os dados qualitativos coletados foram analisados visando compreender os discursos dos árbitros sobre o trabalho da mídia no futebol, e como eles interpretam os comentários da mídia em relação ao trabalho da equipe de arbitragem. As entrevistas foram gravadas em áudio ${ }^{4}$, posteriormente foram digitalizadas por serviço de terceiros e checadas com a gravação por uma das pesquisadoras. As respostas foram analisadas inicialmente no conjunto da entrevista de cada indivíduo. Posteriormente, procuraram-se pontos comuns entre as entrevistas. Estas foram realizadas após os estudos teóricos, o que permitiu a extração e incorporação de falas sobre os temas pesquisados, ou seja, arbitragem e comentários da mídia sobre a atuação dos árbitros.

A teoria do processo civilizatório de Norbert Elias sobre as figurações e as relações de poder e os estudos sobre violência de Elias e Eric Dunning são o nosso referencial teórico.

\footnotetext{
2 Dissertação de mestrado, defendida por Carla Righeto.

3 A escolha foi pelo critério de acessibilidade.

4 Gravador de voz Smartphone Samsung.
} 


\section{AS FIGURAÇÕES ${ }^{5}$ ELIASIANAS E A PARTICIPAÇÃO DA ARBITRAGEM EM PARTIDAS DE FUTEBOL PROFISSIONAL}

A linguagem, constituída por padrões sonoros, que não possuem a mesma representação simbólica em todas as sociedades, é a capacidade que permite aos seres humanos se desenvolverem e transmitirem conhecimento. Segundo Elias (1994, p.114):

O desenvolvimento do conhecimento humano tal como o conhecemos seria impossível sem a capacidade humana única de transmitir conhecimento, sob a forma de componentes da linguagem, de uma geração para a outra. É um facto que o conhecimento, quer seja uma transmissão oral ou uma transmissão por meio de um livro, pode ser comunicado, na forma de uma língua, de uma pessoa para outra, 0 que possibilita a transmissão massiva de conhecimento de uma geração para outra.

Os seres humanos têm a capacidade de comunicar-se e precisam se relacionar com outros indivíduos, pertencer a diferentes grupos e ligações sociais. Somos dependentes da família, escola, trabalho e Estado, mas os outros também são dependentes de nós. Essa teia de interdependência entre as pessoas é chamada por Elias de figurações. Segundo o autor, o que une as pessoas são as diferentes formas de ligações sociais e ligações afetivas relacionadas às necessidades emocionais, econômicas e políticas. Elias considera o futebol como um tipo de figuração social que atua de forma dinâmica e com equilíbrio de tensões entre opostos. Segundo Elias e Dunning (1992, p. 302),

Um desporto ou um jogo é uma "estrutura" ou padrão que um grupo de seres humanos interdependentes forma entre si. Esta estrutura, padrão ou, de forma mais correcta, configuração compreende: 1) dois indivíduos ou equipes que cooperam uma com a outra numa rivalidade mais ou menos amigável; 2) agentes de controlo, como árbitros e juízes de linha; e, 3), por vezes, mas nem sempre um número maior ou menor de espectadores.

Embora esta figuração seja a condição necessária para a existência de um jogo, Elias afirma que ela pertence a configurações mais alargadas, formadas pela organização do clube, os órgãos legislativos e administrativos que formulam as regras, que no futebol compreende as Ligas, Federações e Confederações e que, por sua vez, também estão interligadas com configurações mais vastas num quadro internacional. Para esta rede de interdependência podemos acrescentar as inúmeras redes de pessoas que hoje trabalham e vivem do futebol, ou seja, membros de uma vasta figuração que trabalham nos bastidores para que o futebolespetáculo aconteça são desde os trabalhadores em indústrias de artigos esportivos, operários da construção civil, patrocinadores, jornalistas e comentaristas esportivos e muitos outros profissionais.

As regras garantem a dinâmica de toda a configuração formada pelos jogadores das duas equipes. $O$ árbitro e os assistentes (bandeirinhas) são os responsáveis por manter 0 cumprimento das regras e o equilíbrio destas polaridades opostas, mas que se complementam em um equilíbrio de tensão.

A dinâmica das figurações nos remete a outro conceito desenvolvido por Elias: as relações de poder. Segundo Elias (2008), o termo "poder" sempre é visto por nós como algo "desagradável" por ter sido durante a história do desenvolvimento da sociedade relacionado a

5 Na última obra produzida por Eric Dunning (2014, p. 24 nota 4) no Brasil, o autor apresenta esclarecimentos sobre a mudança de posição de Elias sobre a propriedade do uso da palavra configuração ou figuração para designar grupos de seres humanos. Esclarecendo, portanto, que

o melhor uso é de figuração. Por isso adotamos a última forma em trechos desse artigo que não se trata de citação literal. 
desigualdades sociais, ao abuso e falta de escrúpulos dos considerados mais fortes sobre os mais fracos. Para Elias e Dunning (1992), poder não deve ser entendido como uma "coisa" que alguns indivíduos ou grupos possuem e outros não. Dependemos de outros e outros dependem de nós, o poder deve ser compreendido como uma característica fundamental de todas as relações humanas.

O trabalho dos jornalistas e comentaristas é parte do desenvolvimento do futebolespetáculo. A capacidade de transmitir conhecimento coloca a mídia esportiva em uma situação privilegiada nas relações de poder com os árbitros de futebol, uma vez que ela se favorece dos recursos tecnológicos e do fato de estar em milhões de lares brasileiros.

Elias e Dunning (1992, p.330) estabelecem uma tipologia da violência que se distingue em termos de meios utilizados, intencionalidade da ação e parâmetros sociais, uma vez que diferentes sociedades podem distinguir atitudes violentas de maneira diferenciada. Para os autores, a violência "é real ou simbólica, isto é, se apresenta a forma de uma agressão física directa ou envolve simplesmente atitudes verbais e/ou não verbais". Sendo esta a compreensão e utilização da violência simbólica na pesquisa realizada com os árbitros.

Segundo Reis (2006, p.50), violência é a "[...] utilização da força (física ou não) que atende contra a lei e/ou o direito da soberania da pessoa". Para a autora, a violência não pode ser entendida apenas como força física ou manifestada por contatos físicos. Por isso, ela adere à categoria de violência simbólica de Elias e Dunning (1992) quando se refere a verbalizações de alguém dirigidas a outrem, ou seja, as atitudes manifestas de torcedores e especialistas à equipe de arbitragem ou a outros torcedores são consideradas por Reis (2006) como sendo manifestações de violência simbólica.

Uma particularidade de nossa pesquisa foi nos depararmos com o fato de um dos três árbitros FIFA de São Paulo ser do sexo feminino. Por este aspecto, nos surgiu a reflexão sobre as resistências e dificuldades enfrentadas por mulheres no campo de futebol, sejam elas jogadoras, técnicas ou árbitras. Pois, segundo Reis (2006), os esportes modernos foram construídos culturalmente para os homens, o que significa dizer que, assim como em todos os ramos sociais, também nos esportes a mulher teve e tem de conquistar sua participação e ganhar reconhecimento.

Sendo o esporte criado pelos homens e para os homens, é esperado que as mulheres encontrem dificuldades para serem escaladas e assim arbitrarem partidas de futebol, haja vista a sua ausência no campo de jogo, ainda mais em campeonatos masculinos profissionais. $\mathrm{Na}$ mídia as árbitras que buscam o reconhecimento e se propõem a disputar espaços hegemônicos masculinos convivem com preconceitos e discriminações, que vão desde os estereótipos de homossexual à erotização do corpo feminino, como, por exemplo, pode ser visto em publicações das revistas (FÁBIA..., 1995, A JUİZA..., 1996; GARCIA, 1997; ANA PAULA , 2007; SHOW..., 2008).

Ainda tratando-se do referencial teórico da pesquisa, acrescentamos que, para Elias (2000), a fofoca estabelece crenças coletivas e causa sentimentos de virtude, prazer e excitação. Na sociodinâmica dessa estigmatização, a mídia esportiva e os dirigentes homens atribuem características ruins ao grupo de mulheres e modela o trabalho dos homens na minoria dos melhores. Isso contribui para a exclusão profissional das árbitras, o preconceito, a erotização dos corpos femininos e o estereótipo de homossexual. 


\section{A ENTRADA DOS ÁRBITROS EM CAMPO E A POLÊMICA DE SUA ATUAÇÃO}

O árbitro de futebol é um personagem polêmico, criticado e questionado por dirigentes, comissão técnica, atletas, mídia ${ }^{6}$, torcedores e espectadores; as suas interpretações e decisões são, na maior parte das vezes, compreendidas como má-fé se contrariam a percepção do observador sobre a cena do jogo.

Para Franco Jr. (2007), muitas das regras do futebol são fundamentadas em valores ingleses. A regra do offside, impedimento ou "fora de jogo", que foi introduzida em 1867, estaria relacionada a um fair play?, presente no espírito britânico, segundo os historiadores italianos Antonio Papa e Guido Panico. Para Franco Jr.(2007, p.31), "Fica 'fora de jogo' quem adota comportamento furtivo. Quem se esconde nas costas do adversário para fazer o gol. A regra do offside exigiu a necessidade de alguém presente no jogo, em local privilegiado, a quem os capitães das equipes pudessem se reportar em caso de dúvidas. Surge assim a figura do árbitro de futebol em 1868.

Em um jogo criado para cavalheiros, não se podia compreender que um gentleman pudesse cometer uma falta propositalmente. Talvez seja por esse motivo que no início as regras não previam árbitros e os lances duvidosos durante as partidas eram decididos pelos capitães das equipes. Porém a crescente competitividade entre as equipes no período vem acompanhada do aumento da tensão e das reclamações durante 0 jogo. 0 fato é que as disputas ficaram acirradas e, em 1891, para punir as ações deliberadas dos jogadores, 0 árbitro adentrou o campo.

Em junho de 1886, foi fundada a International Football Association Board (IFAB), com o propósito de acabar com todos os argumentos e divergências das diferentes ligas e associações britânicas, unificando assim as regras entre elas. A International Football Association Board é até os dias de hoje a "guardiã" das regras do jogo em todo o mundo. Criticada por ser considerada uma instituição conservadora e que dificulta a modernização do futebol, a IFAB se defende justificando que muitas alterações propostas estariam mudando a essência do futebol, que, segundo Franco Jr. (2007), teve muitas das suas regras escritas fundamentadas em valores ingleses.

A FIFA foi fundada em 21 de maio de 1904, em Paris. Os ingleses eram contrários à sua fundação por acreditarem ser a FA a única autoridade no esporte. Segundo Boschilia (2008, p.89), "[...] a condição de que a IFAB fosse responsável pelas modificações das regras do futebol, a Inglaterra, após duas desfiliações, voltaria a figurar no quadro de membros da FIFA, até hoje, somente em 1946".

A FIFA tem atualmente 209 federações nacionais associadas. Qualquer federação nacional associada à FIFA pode enviar propostas de modificação das regras, que serão estudadas, analisadas e votadas pelos membros da IFAB. Cada uma das federações britânicas tem direito a um voto, totalizando quatro votos. A FIFA, representando as 205 federações nacionais, tem direito a quatro votos. Para que uma regra seja modificada são necessários $3 / 4$ dos votos, portanto seis votos.

As regras passaram por duas grandes modificações (FIFA, 2016), no final da década de 1930 e uma segunda revisão somente em 1997. A FIFA e a IFAB mantêm suas posições 
de entidades conservadoras quando o assunto é alterar as regras do jogo. Poucas foram as alterações significativas que auxiliaram o trabalho da arbitragem. A possibilidade dos árbitros utilizarem uniformes de várias cores suavizou sua imagem, porém parece ter atendido muito mais aos interesses dos patrocinadores dos materiais esportivos, das instituições e das imagens do espetáculo do que para atender aos interesses dos próprios árbitros. Coincidentemente ou não, a utilização dos cartões amarelo e vermelho vem acompanhando as transmissões em cores pela televisão. Antes da Copa de 1970 as advertências aos jogadores eram anotadas em cadernetas. Um jogador que fosse expulso seria acompanhado pelo árbitro até a linha lateral do campo. A bandeira eletrônica, recurso utilizado pela primeira vez na Copa de 1998, favoreceu a comunicação entre o árbitro e os assistentes.

O chip na bola e os sensores instalados dentro da baliza (gol) possibilitaram ao árbitro a confirmação do gol. ${ }^{8}$ Um sinal é transmitido no relógio do árbitro quando a bola ultrapassa totalmente a linha de gol. $O$ recurso do videotape, presente em algumas modalidades esportivas, para que em momentos decisivos e importantes de uma partida possa ser consultado pelo árbitro, não é autorizado no futebol. Em março de 2016 a IFAB autorizou testes do árbitro de vídeo, porém o uso de imagens para auxiliar o árbitro será restrito a quatro situações específicas: lances de gol, pênalti, cartão vermelho e identificação errada de jogador punido. Os vídeos não serão utilizados para lances de impedimentos. Segundo Reis e Escher (2005), com narrações entusiasmadas, replays e super imagens, os torcedores saem do estádio com vontade de rever os melhores momentos da partida e sanarem suas dúvidas sobre os lances duvidosos na TV, neste sentido as "mesas-redondas" satisfazem o telespectador torcedor.

Lances polêmicos, repetidos à exaustão, incriminam aquele que não poderia ter errado, tendo uma única chance de decidir. Sendo o jogo transmitido para milhões de telespectadores, muito desses jornalistas (especialistas) formadores de opinião parecem não compreender a importância e a responsabilidade de seus comentários direcionados a todos os participantes do espetáculo esportivo. Para Simon (2004, p.100):

\begin{abstract}
Observar os jogos por meio de recursos eletrônicos de que hoje se pode dispor numa emissora de TV é uma coisa completamente diferente de apitar um jogo. Por isso, parece essencial que o analista mantenha sempre um rigoroso distanciamento crítico: tem que levar em conta as circunstâncias em que está envolvido o árbitro: frações de segundo para tomar uma decisão, visão de jogo desde o mesmo plano em que ele acontece etc. $O$ árbitro em campo não conta com um monitor de TV que lhe mostre o lance repetidas vezes. Deveria ter um?
\end{abstract}

A mídia é formadora de opinião, muitas vezes contribui para a violência entre torcedores de futebol e a violência contra a equipe de arbitragem. Comentários que provocam um clima de guerra parecem fazer parte inclusive da propaganda do jogo de futebol. A violência simbólica contra a equipe de arbitragem é estimulada pelos jornalistas e comentaristas quando estes analisam os erros dos árbitros.

Carlos Eugênio Simon, representante da arbitragem brasileira nas Copas de 2002, 2006 e 2010, considera que a presença de analistas de arbitragem nas emissoras de TV tem, por um lado, contribuído para que o torcedor conheça melhor as regras do jogo, no entanto apesar da credibilidade de que desfrutam esses por terem sido árbitros, o telespectador ou ouvinte não deveria considerar sua opinião "definitivamente inequívoca" (SIMON, 2004, p.100). 
Segundo o árbitro de futebol espanhol Eduardo Gonzalez, entrevistado no programa Liga Confidencial da ESPN Internacional9: "Este é um jogo no qual o único em desvantagem é 0 árbitro. Por quê? Porque nos julgam com 20 câmeras contra dois olhos. Eu só tenho um ângulo. E tomara que esteja bem posicionado para ver este ângulo".

A discussão sobre o uso da tecnologia na arbitragem é um assunto frequente e divergente em todas as esferas do futebol. Os opositores aos recursos tecnológicos alegam que as gozações dos torcedores fazem parte da essência e da magia do futebol. Perguntamos aos árbitros se eles são a favor do uso da tecnologia para auxiliar o trabalho da equipe de arbitragem.

Depende que tipo de tecnologia, hahaha. Se for a tecnologia que vai beneficiar 0 árbitro eu sou. No caso de rádio comunicadora que as equipes de arbitragem usam o sistema de detectar o gol, que eles têm um relógio se a bola entrou totalmente ou não, chega um sinal sonoro no braço do árbitro e ele pode validar o gol ou não, esse tipo de tecnologia é híper, súper válido (ENTREVISTADA 1).

Sou a favor em alguns aspectos, hoje já temos a bandeira eletrônica que nos auxilia, né, o rádio auxiliador que fica praticamente 0 tempo todo ligado em outros participantes. Porém, assim, eu sou a favor assim, chip na bola, entrou ou não entrou a bola porque, o impedimento pode até ser utilizado, também ou é oito ou é oitenta, mas alguns lances são interpretativos, e às vezes você pega uma imagem, você coloca nos programas esportivos ali, três acham que foi pênalti, quatro acham que não foi, então o que não foi, você corre risco de parar o lance pra ver na TV e tirar uma conclusão, então em alguns aspectos sim, em outros que são interpretativos não (ENTREVISTADO 2).

Eu sou favorável sim à tecnologia, mas essa que foi utilizada para a Copa do Mundo, gol e não gol. É muito triste, é muito complicado principalmente pra nós árbitros você terminar uma partida, você saber que aquele resultado final não foi legitimado por conta de uma decisão. A bola entrar, você não vê, e você não dar um gol, então uma partida que poderia ter terminado um a zero, termina zero a zero, ou você dar o gol numa bola que não entrou. Para mim essas duas situações deveriam sim, como foi feito na Copa do Mundo ter a utilização da tecnologia, gol, não gol. Mas agora a gente não é pra colocar a tecnologia em todas as decisões, o futebol que já tem aí uma duração de duas, quase duas horas, passaríamos pra duas horas e meia, três horas, eu acho que isso ficaria mais complicado. Eu não sou favorável em todas as situações, em todas as decisões. Mas essa de gol e não gol, aí sim na maioria das vezes o resultado pode não ser legitimado, por causa de uma decisão que eu tomei durante a partida (ENTREVISTADO 3).

Sobre o uso da tecnologia na arbitragem, os árbitros que participaram da pesquisa são favoráveis, porém com ressalvas. Concordam que a tecnologia ajuda a legitimar resultados, mas demonstram dúvidas de como e em quais situações esses recursos seriam utilizados, demonstrando preocupações com a dinâmica do jogo. Nas entrevistas, ao serem questionados se eles concordavam com o uso da tecnologia, disseram:

[...] eu não concordo. Porque eu acho que ia acabar aquela cultura de, no outro dia chegar e comentar com o amigo, aquela brincadeira no trabalho, na família de: 'ah seu time perdeu, seu time ganhou e coisa e tal. Eu que a, o futebol ele é muito dinâmico por isso que até hoje num, num entrou esse tipo de recurso pra, no tênis pode fazer se foi dentro ou foi fora, no vôlei dá pra ver, mas o futebol é muito dinâmico. Já pensou? São 90 minutos, às vezes quando para pra um atendimento, pra um, pra uma substituição, pra qualquer coisa parecida o árbitro já dá um monte

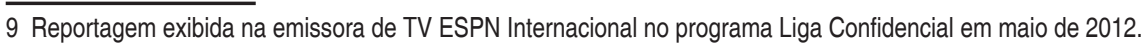


de acréscimo e já foi pouco, imagina se você parar pra decidir: 'peraí, vamo [...] olha no monitor se foi, não foi' (ENTREVISTADA 1).

É só que esses jogos vão ser utilizados que recurso, jogos de Copa do Mundo, jogos de competições maiores assim, porque não tem condição de você fazer isso no estadual, por exemplo, não tem recurso e acho que é um custo alto porque tem que ter câmera, tem que ter muitas câmeras. Porque duas câmeras no estádio às vezes podem acontecer um lance que eu vi no vôlei o lance, que o jogador deu um peixinho assim colocou a mão pra bola bater que nenhuma câmera pegou a pedido da FIVA acho que tinha lá 12 câmeras, no ginásio, e as únicas câmeras que tinham que conseguiriam visualizar o lance tinham jogadores na frente, então tinha jogadores e não viram o lance (ENTREVISTADO 2).

Na polêmica e no desafio, o medo é que o futebol chegue nesse desafio que toda decisão que você tomar no jogo alguém que vê o direito de parar aquele jogo, voltar a essa decisão (ENTREVISTADO 3).

Nos lances que podem decidir uma partida de futebol, 0 árbitro tem atualmente 0 auxílio dos assistentes e do quarto árbitro que, trabalhando nas laterais do campo, têm um ângulo de visão diferente do árbitro central. $\mathrm{O}$ uso da tecnologia ajudaria nas decisões, mas não podemos esperar que o uso das imagens solucione todo o problema da polêmica das interpretações das jogadas. Vejamos o que diz o jornalista Antero Greco comentando uma jogada no jogo Corinthians X Avaí do Campeonato Brasileiro de 2015. "Lance que precisou ser passado, reprisado, analisado com tira-teima para se chegar a alguma conclusão - e ainda assim contraditória" (GRECO, 2015, p.2). Quer dizer, em muitos lances do futebol, mesmo com o uso de recursos tecnológicos, haverá dúvidas quanto à decisão tomada pela equipe de arbitragem.

Os programas esportivos ganham audiência e rendem horas de exposição na mídia esportiva televisiva comentando os erros da equipe de arbitragem. Os erros e acertos são 0 assunto das rodas de amigos, principalmente após a rodada do final de semana e se todos os brasileiros são técnicos de futebol, às segundas-feiras também são os melhores árbitros. $O$ fato é que erros de arbitragem sempre existirão, assim como os erros dos jogadores, porém os torcedores parecem ser mais complacentes com os erros dos jogadores. 0 árbitro jamais pode errar.

Pesquisa realizada na Universidade Católica Australiana em Sidney, por Baldwin (2008), tinha por objetivo examinar se o trabalho realizado por comentaristas e jornalistas esportivos, quando analisam o trabalho da arbitragem, causa stress e ansiedade nos árbitros e pode interferir nas tomadas de decisões destes, durante uma partida. Para os árbitros entrevistados a mídia exagera nos comentários sobre os supostos erros da arbitragem, os árbitros sentem-se "incomodados" ao ouvirem ou lerem os artigos publicados e as análises das partidas e acreditam que os jornalistas e analistas esportivos têm pouco conhecimento sobre esportes. A conclusão da pesquisa mostra que a mídia, embora não seja a única responsável, causa stress e ansiedade nos árbitros. Utilizando-se de uma linguagem agressiva e de recursos tecnológicos, expõe os árbitros e contribui para uma imagem negativa deles na sociedade.

Para Betti (1997, p. 132), "Mas não é também isso - polêmica, dúvida e discussão que torna o futebol tão apaixonante às multidões, e é objeto privilegiado na temática da própria mídia". O fato é que o árbitro é também responsável pelo sucesso de público e financeiro do espetáculo. 
Na busca de compreender qual é a percepção dos árbitros sobre a violência, perguntamos aos nossos entrevistados o que eles entendem por violência:

Olha, eu acho que a violência é a incapacidade do ser humano não conversar, não resolver no diálogo. [...] violência verbal, agressão verbalmente ou até mesmo agressão física. Então eu acho que a violência, a incapacidade do ser humano de poder tentar esclarecer as diferenças, a esclarecer a opinião, falar a dele, escutar a do outro e respeitar, ter a capacidade do ser humano a respeitar as diferenças (ENTREVISTADA 1).

[...] tudo que tenta denegrir sua imagem, seu trabalho, eu acho que pode ser entre aspas aí, consideradas uma violência (ENTREVISTADO 2).

Ah eu acho que, que seria de um modo geral a violência é você expor um indivíduo, não diria nem adversário. Você expor um indivíduo a uma situação constrangedora. Se essa violência da forma, da forma que parecer, seja lá uma ofensa moral ou até mesmo vias de fato, a violência pode acontecer de varias maneiras hoje, então por meio eletrônico (ENTREVISTADO 3).

Os árbitros interpretam a violência como falta de respeito, falta de capacidade de dialogar, a exposição de um indivíduo a situações constrangedoras e a tentativa de denegrir a imagem, neste caso, do profissional árbitro. Na nossa compreensão enquadram-se na categoria de violência simbólica, sendo mencionado que essas experiências sofridas são frequentes em suas carreiras.

Outra questão que buscamos compreender foi sobre como os árbitros percebem os comentários da mídia sobre suas atuações:

Como eu falei é desumano essa, esse tipo de análise, porque um comentarista de futebol ele tá equipado de várias câmeras, várias imagens que chega pra ele, ele vê 4,5 vezes pra ele poder dar o parecer dele. 0 árbitro vai decidir ali em 3 segundos, com a foto que ele tirou aquele momento. $\mathrm{E}$ aí depois o comentarista de arbitragem crucifica o árbitro por causa daquele erro, mas porque ele viu na tecnologia, e a maioria dos comentaristas de futebol são ex-árbitros e eles na época deles, geravam muito mais, mais muito mesmo. Só que não tinha câmera pra ser cobrado, então hoje tá fácil pra ele comentar ou não na verdade, comentar o árbitro, hoje tá fácil pra ele porque tem milhões de câmeras pra ele olhar. Será que ele lembra quando ele tava lá no jogo? Qual era a dificuldade que ele tinha, o quão era difícil apitar uma partida de futebol, pra hoje ele ficar criticando o árbitro, formando opinião. Eu acho, eu não vou nem falar o que eu acho, eu acho um absurdo (ENTREVISTADA 1).

[...] tem melhorado muito hoje, né, eu acho que a mídia assim, uma boa parte da mídia ela vem junto com, buscando o melhor espetáculo assim, e devido aos últimos acontecimentos da Copa do Mundo, a gente vive um país fora do futebol que todo mundo tá um pouco de saco cheio, né? Então eu acho que a mídia em termos de jogador, de arbitragem a mídia tá batendo mais do que batia antes, mas eu acho que também tem muita mídia que é torcedora ainda, e às vezes dão muita voz assim, quando alguém quer transferir o resultado pro árbitro (ENTREVISTADO 2).

Eu acho que ela poderia ajudar muito mais com informações que mostra aí, principalmente como a população, os torcedores, ganharam com os comentaristas de arbitragem, desde lá dos primeiros que vieram a trabalhar, hoje, quase todos os canais têm um comentarista de arbitragem. Então quanto mais a gente puder divulgar as regras de jogo pra que as pessoas entendam o mínimo de regra do jogo, facilita a nossa vida. Mas agora se for aquela mídia bairrista, torcedora, não 
vai somar em nada, não vai ajudar em nada, a gente sabe que tem muito torcedor trabalhando na mídia, tem muitas pessoas, acaba tendo o time tem paixão por determinada equipe, mas a gente acaba respeitando. [...] Agora se for aquela mídia que vem pra esclarecer, que vem pra tirar a dúvida do torcedor, pra mostrar realmente quando a gente falha, quando a gente se equivoca, quando a gente erra aí sim a gente a gente somos favoráveis (ENTREVISTADO 3).

O trabalho dos jornalistas e comentaristas recebe duras críticas dos árbitros que consideram desumanas as avaliações feitas pela mídia, uma vez que os jornalistas e comentaristas possuem recursos de análises não disponíveis aos árbitros. Esperam um trabalho mais informativo, que os profissionais da mídia se atualizem sobre regras e se mostram desapontados com os profissionais que não conseguem separar o trabalho jornalístico do seu lado torcedor de futebol.

Sendo a mídia formadora de opinião, o que pensam os árbitros sobre a responsabilidade da mídia na violência entre torcedores de futebol e sobre a violência contra a equipe de arbitragem? Segundo os árbitros:

[...] tem muito comentarista que nunca pegou um livro de regra, não sabe nem quantas regras têm no futebol e ele comenta absurdos, isso ele forma uma opinião. Se ele forma uma opinião negativa em relação a árbitro, ele tá indiretamente ou diretamente insultando pouco aquilo ali. Ele acaba sendo responsável sim, pela violência nos estádios, violência com os árbitros, com os assistentes porque a gente tem alguns casos que 0 árbitro, a equipe de arbitragem foi agredida ou insultada, ou a caminho do estádio, em tudo isso eu acho que a mídia tem uma grande responsabilidade porque ela é formadora de opinião. Então às vezes eles fazem um tipo de comentário desnecessário e errôneo, quando comenta desnecessariamente, [...]. E às vezes tem coisa que não adianta passar, ao não ser a incitar a violência (ENTREVISTADA 1).

Eu acho assim, esses jornalistas que dão muita ênfase, como eu falei anteriormente nessa transferência de responsabilidade do árbitro, ou dirigente que quer jogar tudo nas costas do árbitro porque essas respostas que eles tão dando não é pra mídia, não é pra mim, tá falando pros torcedores deles, que ao invés de falar que 'Ah, o time tá mal, mexeu errado, perdeu'. Não, eles preferem falar pros torcedores deles, talvez essa violência pode acontecer pelas palavras que eles tão usando não que aconteceu dentro do campo (ENTREVISTADO 2).

Eu acho que poderia ser melhor, eu acho que poderia ser melhor na forma que eles vendem, às vezes, um clássico ou uma partida buscando o que já aconteceu no passado, o que for principalmente de uma forma negativa, ao invés de ajudar eu acho que apimenta muito mais, coloca ainda muito mais emoção. Já se cria um clima desfavorável pra que você possa levar família pro campo de jogo, levar um filho, levar um parente. [...] principalmente quando um equívoco, um erro que às vezes acontece de uma forma que ninguém quer e a forma como é passada, repassa essa informação tanto ali no rádio, principalmente no rádio, né, que são pesos locais, na maioria das vezes. A forma como eles colocam mexe com o emocional e consequentemente com a segurança da arbitragem pós-jogo. Porque dentro de campo todos veem, nós temos três, cinco, dez, quinze policiais a nossa volta. Mas no dia seguinte? E o aeroporto, e a rodoviária, e a estrada, e o restaurante que você tá no dia seguinte correndo esse risco de encontrar esse torcedor, principalmente quando você acerta e eles defendem até o último momento que 0 árbitro se equivocou naquela decisão que todos já viram que tinha acertado. Então ela poderia, assim como eu coloquei dos comentaristas de arbitragem, poderia ser uma mídia mais esclarecedora que defende às vezes uma opinião de que todos tão vendo que foi de uma forma contrária (ENTREVISTADO 3). 
Os árbitros responsabilizam a mídia pela violência nos estádios e contra a equipe de arbitragem. Atribuem a violência entre os torcedores pela maneira como a mídia "vende o jogo" para que o clima de rivalidade aumente a audiência. A violência contra a equipe de arbitragem é estimulada por comentários de supostos erros nas interpretações e tomada de decisão dos árbitros, análises estas, segundo os árbitros, nem sempre fundamentadas e corretas.

Ao definirmos que os árbitros entrevistados para esta pesquisa seriam os árbitros FIFA da Federação Paulista de Futebol, nos surpreendemos com a presença de uma mulher entre os três árbitros desta categoria. A nossa surpresa se deve ao fato de que, embora faça parte da elite da arbitragem brasileira, esta mulher não atua nas competições da categoria profissional masculina porque nunca é escalada. Aos árbitros homens de categorias inferiores (aspirante ao quadro internacional e árbitros nacionais) são oferecidas oportunidades em jogos nos quais as árbitras nacionais e a nossa entrevistada (FIFA) não são escaladas, mesmo tendo uma categoria superior a muitos dos árbitros homens que são escalados.

Segundo um dos nossos entrevistados ${ }^{10}$, a mulher árbitra ser aprovada em todas as avaliações físicas e teóricas não the garante o direito de ser escalada em jogos masculinos da categoria profissional. Tanto os dirigentes da Federação Paulista de Futebol como os dirigentes da Confederação Brasileira de Futebol não oportunizam o trabalho das árbitras, portanto não as reconhecem nas suas respectivas categorias: nacionais e FIFA.

Perguntamos à nossa entrevistada, árbitra FIFA, se ela considerada o fato de não ser escalada uma forma de violência:

Eu considero sim, porque como você falou, nós mulheres... Tem eu que sou FIFA, e tem mais quatro árbitras centrais na Federação Paulista de Futebol e realmente a gente não tem as mesmas oportunidades que tem os homens, que são mesmas categorias, é de referência, né ? No caso eu sou categoria 1, eu não tenho 0 mesmo número de jogos que a outra categoria tem, se eu tô na categoria 1 eu tenho que ter o mesmo número de jogos. Aí os que estão na mesma categoria não têm o mesmo número de jogos, quer dizer, a gente tem menos número de jogos, menos oportunidade, pra mim é pelo simples fato de ser mulher sim, porque nós somos cobradas da mesma forma, nós somos cobradas no mesmo teste físico, prova teórica, no procedimento a seguir o regulamento, só que na hora de ter 0 retorno da mesma forma a gente não tem, infelizmente. Mas pra mim é um tipo de violência sim, porque nós estamos aí lutando pelo nossos espaços, fazendo tudo que eles são obrigado a fazer. 'Ah, mas pra vocês são diferentes'. Mas nós somos diferentes porque a gente quer que seja diferente, a gente faz 0 que a gente tem que fazer, então pra mim é um tipo de violência sim, pelo simples fato de ser mulher, porque tem muita resistência ainda e tem muito preconceito. Mas infelizmente, infelizmente tem.

Analisar os comentários da mídia em partidas arbitradas por mulheres da categoria profissional masculina não foi possível, uma vez que os dirigentes não escalam mulheres para estes jogos como árbitras centrais. No período de 2001 a 2007 a árbitra internacional de futebol Sílvia Regina de Oliveira atuou em jogos do Campeonato Paulista Masculino ${ }^{11}$. Na época os jornalistas e comentaristas discutiam se uma mulher apresentava capacidade técnica e física para atuar em partidas masculinas, porém a árbitra já havia sido aprovada nos testes da Federação Paulista de Futebol. 
Para Reis (1998, p.46), "Os esportes modernos foram construídos culturalmente pelos homens, o que significa dizer que, assim com em todos os ramos sociais, também nos esportes a mulher teve de conquistar sua participação e ganhar reconhecimento."

Entendemos a recusa em escalar mulheres como violência simbólica e de gênero uma vez que elas cumprem as mesmas etapas de formação para árbitros e são aprovadas nos mesmos testes técnicos e físicos exigidos pela FPF nas pré-temporadas.

\section{CONSIDERAÇÕES FINAIS}

Nossos entrevistados entendem a violência contra árbitros como falta de capacidade para dialogar, expor os árbitros a situações constrangedoras, denegrir a imagem do profissional e ser humano. Os jornalistas e comentaristas se beneficiam de recursos tecnológicos e fazem avaliações do trabalho da equipe de arbitragem consideradas por eles como desumanas. Impossibilitado de usufruir dos mesmos recursos tecnológicos e devendo decidir em frações de segundo, o árbitro de futebol é execrado nos programas esportivos e não tem direito a se manifestar. A mídia, segundo os árbitros e a literatura apresentada, também é responsável pela violência no futebol. Os árbitros demonstram desapontamento e esperam um trabalho mais informativo e menos "torcedor" de toda a mídia. Os erros fazem parte da "condição humana" e perguntamos: quem gostaria de errar diante das várias câmeras de televisão? Os árbitros entrevistados são vítimas da violência simbólica presente nos comentários da mídia.

A falta de civilidade e respeito se agrava no trato com as mulheres árbitras que trabalham para ganhar reconhecimento e conquistar relações igualitárias nas escalas dos jogos de futebol. A impossibilidade de trabalhar em jogos profissionais masculinos é vista como uma forma de violência simbólica contra a mulher. Pensamos que esta conquista, para as mulheres, não apenas na arbitragem do futebol, mas em todos os espaços sociais, precisa ser acompanhada de conquistas em cargos de gestão das instituições esportivas no Brasil. Enquanto os homens estiverem confortavelmente instalados nesses cargos e monopolizarem as decisões, dificilmente as mulheres encontrarão respeito e as mesmas oportunidades que os homens na arbitragem brasileira.

\section{REFERÊNCIAS}

ANA Paula: a bandeirinha mais gostosa do mundo! Playboy, capa, jul. 2007.

BALDWIN, Christopher. The ref cost us the game: The role of sports commentators and journalists in creating stresses on sports referees. Disponivel em: <http://mrfootball.net/refereebias/The\%20 ref $\% 20$ cost $\% 20$ us $\% 20$ the $\% 20$ game $\% 20$ The $\% 20$ role $\% 20$ of $\% 20$ sports $\% 20$ commentators $\% 20$ and $\% 20$ journalists\%20in\%20creating\%20stresses\%20on\%20sports\%20referees.pdf>. Acesso em: 2 mar. 2017.

BETTI, Mauro. Violência em campo: dinheiro, mídia e transgressão as regras no futebol espetáculo. ljuí: Unijuí, 1997.

BOSCHILIA, Bruno. Futebol e Violência em Campo: análise das interdependências entre árbitros, regras e instituições esportivas. 2008. 192 f. Dissertação (Mestrado em Educação Física), Departamento de Educação Física, Setor de Ciências Biológicas, Universidade Federal do Paraná, Curitiba, 2008. 
COELHO, Arnaldo Cezar. A regra é clara. São Paulo: Globo, 2002.

DUNNING, Eric. Sociologia do esporte. São Paulo: Annablume, 2014.

ELIAS, Norbert; SCOTSON, John. Os estabelecidos e os outsiders. Rio de Janeiro: Jorge Zahar, 2000.

ELIAS, Norbert. Introdução à Sociologia. Lisboa: Edições 70, 2008.

ELIAS, Norbert. Teoria Simbólica. Oeiras: Celta, 1994.

ELIAS, Norbert; DUNNING, Eric. A busca da excitação. Lisboa: DIFEL, 1992.

ESCHER, Tiago Aragão; REIS, Heloisa Helena Baldy. Futebol e Televisão: Fechem os portões liguem as câmeras - o show vai começar! Conexões, v.3, n.1,2005. Disponível em: <http://periodicos. sbu.unicamp.br/ojs/index.php/conexoes/article/view/8637886>. Acesso em: 17 nov. 2016.

FÁBIA Tafarel: no vestiário com a Deusa, Placar, n.1106., ago. 1995.

FÉDERATION INTERNATIONALE DE FOOTBALL ASSOCIATION. Disponível em: < www.fifa.com>. Acesso em: 2 mar. 2017.

FRANCO JÚNIOR, Hilário. A dança dos deuses: Futebol, Cultura e Sociedade. São Paulo: Companhia das Letras, 2007.

GARCIA, Sérgio. Gostosas! Haja coração: Quem são as Deusas do futebol feminino. Placar, n. 1125, p. 22-32, mar. 1997.

GRECO, Antero. "E as polêmicas persistem...". O Estado de S. Paulo, São Paulo, 17 ago 2015, Caderno de Esportes, p.2.

A JUÍZA mais gostosa do Brasil. Placar, n. 1111, capa, jan. 1996.

REIS, Heloisa Helena Baldy. Futebol e Violência. Campinas: Autores Associados, 2006.

REIS, Heloisa Helena Baldy; ESCHER, Tiago Aragão. Futebol e Sociedade. Brasília: Líber livro, 2006.

RIGHETO, Carla. "Árbitros: vilões e/ou mediadores do espetáculo?". 2016. 121 f.. (Dissertação Mestrado em Educação Física)- Campinas: Faculdade de Educação Física, Universidade Estadual de Campinas, 2016.

SHOW DE bola: Laísa Adrioli, atacante do Inter vem pra galera. Sexy, p.42-63, mar. 2008.

SIMON, Carlos Eugênio. Na diagonal do Campo. São Leopoldo: Unisinos, 2004.

TOLEDO, Luís Henrique. Lógicas no Futebol. São Paulo: Hucitec/Fapesp, 2002. 